\title{
PRELIMINARY PHYTOCHEMICAL ANALYSIS AND CYTOTOXICITY POTENTIAL OF PINEAPPLE EXTRACT ON ORAL CANCER CELL LINES
}

\author{
ANIRUDH MENON ${ }^{1 *}$, VISHNU PRIYA $V^{2}$, GAYATHRI R ${ }^{2}$
}

${ }^{1}$ Department of Biochemistry, Saveetha Dental College, Saveetha University, Chennai, Tamil Nadu, India. ${ }^{2}$ Department of Biochemistry, Saveetha Dental College, Saveetha University, Chennai, Tamil Nadu, India. Email: aniruddhmenon@icloud.com

Received: 07 June 2016, Revised and Accepted: 22 June 2016

\section{ABSTRACT}

Objective: This study aims at performing a preliminary phytochemical analysis to evaluate the phytochemical composition of pineapple extract and its cytotoxicity potential on oral cancer cell lines.

Methods: Preliminary phytochemical analysis of pineapple extract was done, 3-(4, 5-Dimethyl-2-thiazolyl)-2, 5-diphenyl-2H-tetrazolium bromide assay for evaluating the cytotoxicity potential of the extract on oral cancer cell lines was performed.

Results: Phytoconstituents such as flavonoids, coumarins, and phenols were present in the pineapple extract. The extract also exhibited increased cytotoxicity with increased concentration.

Conclusion: This study is conducted to see if pineapple extract is effective in treating oral cancer in a natural way instead of harmful treatments.

Keywords: Cytotoxicity, Pineapple extract, Anticancer drug

(C) 2016 The Authors. Published by Innovare Academic Sciences Pvt Ltd. This is an open access article under the CC BY license (http://creativecommons. org/licenses/by/4. 0/) DOI: http://dx.doi.org/10.22159/ajpcr.2016.v9s2.13313

\section{INTRODUCTION}

Pineapples have a long tradition as a medicinal plant among the natives of South and Central America. The first isolation of bromelain was recorded by the Venezuelan chemist Vicente Marcano, in 1891, by fermenting the fruit of pineapple. In 1892, Russell Henry Chittenden, assisted by Elliott P. Joslin and Frank Sherman Meara, investigated the matter more completely, and called it "bromelin." Later, the term "bromelain" was introduced and originally applied to any protease from any member of the plant family Bromeliaceae.

Bromelain is present in all parts of the pineapple plant, but the stem is AQ3 the most common commercial source [citation needed], presumably because large quantities are readily available after the fruit has been harvested. A concentrate of proteolytic enzymes enriched in bromelain is approved in Europe for the debridement (removal of dead tissue) of severe burn wounds under the trade name NexoBrid. Bromelain has not been scientifically proven to be effective in treating any other diseases, and it has not been licensed by the Food and Drug Administration for the treatment of any disorder. Available in some countries as a product under the name Ananase, bromelain began its reputation for various uses in folk medicine. As a potential anti-inflammatory agent, it may be useful for treating arthritis but has neither been confirmed in human studies for this use nor is it approved with a health claim for such an effect by the Food and Drug Administration or European Food Safety Authority.

While there have been studies which positively correlated the use of bromelain with reduction of symptom severity in osteoarthritis, the majority of the studies have methodological issues that make it difficult to draw definite conclusions, as none definitively established efficacy, recommended dosage, long-term safety, or adverse interaction with other medications. Systemic enzyme therapy (consisting of combinations of proteolytic enzymes such as bromelain, trypsin, chymotrypsin, and papain) has been investigated in Europe to evaluate the efficacy of proteolytic enzymes in the treatment of breast, colorectal, and plasmacytoma cancer patients. Bromelain supplements, when taken with other medications (amoxicillin, antibiotics, anticoagulant/ antiplatelet drugs), may increase the risk associated with heart rate, blood clotting, and bleeding after surgery.

\section{Cytotoxicity}

Cytotoxicity is the quality of being toxic to cells. Examples of toxic agents are an immune cell or some types of venom, e.g., the Black Widow spider or The King Cobra.

Cytotoxicity assays are widely used by the pharmaceutical industry to screen for cytotoxicity in compound libraries. Researchers can either look for cytotoxic compounds if they are interested in developing a therapeutic that targets rapidly dividing cancer cells, for instance; or they can screen "hits" from initial high-throughput drug screens for unwanted cytotoxic effects before investing in their development as a pharmaceutical. Assessing cell membrane integrity is one of the most common ways to measure cell viability and cytotoxic effects. Compounds that have cytotoxic effects often compromise cell membrane integrity. Vital dyes, such as trypan blue or propidium iodide, are normally excluded from the inside of healthy cells; however, if the cell membrane has been compromised, they freely cross the membrane and stain intracellular components [1]. Alternatively, membrane integrity can be assessed by monitoring the passage of substances that are normally sequestered inside cells to the outside. One molecule, lactate dehydrogenase (LDH), is commonly measured using LDH assay. LDH reduces nicotinamide adenine dinucleotide (NAD) to NAD hydrogen which elicits a color change by interaction with a specific probe [2]. Protease biomarkers have been identified that allow researchers to measure relative numbers of live and dead cells within the same cell population. The live-cell protease is only active in cells that have a healthy cell membrane and loses activity once the cell is compromised, and the protease is exposed to the external environment. The dead cell protease cannot cross the cell membrane and can only be measured in culture media after cells have lost their membrane integrity [3].

Cytotoxicity can also be monitored using the 3-(4, 5-dimethyl-2thiazolyl)-2,5-diphenyl-2H-tetrazolium bromide (MTT) or with 2,3-bis(2-methoxy-4-nitro-5-sulfophenyl)-2H-tetrazolium-5-carboxanilide (XTT), which yields a water-soluble product, or the MTS assay. This assay measures the reducing potential of the cell using a colorimetric reaction. Viable cells will reduce the MTS reagent to a colored formazan product. A similar redox-based assay has also been developed using the fluorescent dye, resazurin. In addition to using dyes to indicate 
the redox potential of cells to monitor their viability, researchers have developed assays that use ATP content as a marker of viability [1]. Such ATP-based assays include bioluminescent assays in which ATP is the limiting reagent for the luciferase reaction [4].

Cytotoxicity can also be measured by the sulforhodamine B (SRB) assay, WST assay, and clonogenic assay.

Suitable assays can be combined and performed sequentially on the same cells to reduce assay-specific false-positive or false-negative results. A possible combination is LDH-XTT-NR (neutral red assay)-SRB which is also available in a kit format.

A label-free approach to follow the cytotoxic response of adherent animal cells in real time is based on electric impedance measurements when the cells are grown on gold-film electrodes. This technology is referred to as electric cell-substrate impedance sensing. Label-free realtime techniques provide the kinetics of the cytotoxic response rather than just a snapshot like many colorimetric endpoint assays.

Phytotoxicity is a toxic effect by a compound on plant growth [5]. Such damage may be caused by a wide variety of compounds including trace metals, salinity, pesticides, phytotoxins, or allelochemicals. In recent years, multiple drug/chemical resistance in both human and plant pathogenic organisms have been developed due to indiscriminate use of commercial antimicrobial drugs/chemical commonly used in the treatment of infectious diseases [18].

Phytochemicals are defined as bioactive non-nutrient plant compounds in fruits, vegetables, grains, and other plant foods that have been linked to reducing the risk of major chronic diseases. Thousands of phytochemicals have been identified so far, and scientists have only begun to investigate their promise. Cytotoxicity is the degree to which an agent has specific destructive action on certain cells. It is the possession of destructive action, particularly in cell lysis by immune phenomena. Assessing phytocompound cytotoxicity is also a critical step in drug development. These assays are used to evaluate both compound toxicity and inhibition of tumor cell growth during drug designing.

\section{Inorganic compounds}

High concentrations of mineral salts in solution within the growing medium can have phytotoxic effects. Sources of excessive mineral salts include infiltration of seawater and excessive application of fertilizers. For example, urea is used in agriculture as a nitrogenous fertilizer, but if too much is applied, phytotoxic effects can result, either by urea toxicity or by the "ammonia produced through hydrolysis of urea by soil urease" [6]. Acid soils may contain high concentrations of aluminum (as $\mathrm{Al} 3+$ ) and manganese (as $\mathrm{Mn2+}$ ) which can be phytotoxic [7].

\section{Herbicides}

Herbicides are designed to kill plants and are used to control unwanted plants such as agricultural weeds. However, herbicides can also cause phytotoxic effects in plants that are not within the area over which the herbicide is applied, for example, as a result of wind-blown spray drift or from the use of herbicide-contaminated material (such as straw or manure) being applied to the soil [8]. The phytotoxic effects of herbicides are an important subject of study in the field of ecotoxicology.

\section{METHODS}

\section{Phytochemical tests}

\section{Test for carbohydrates}

To $2 \mathrm{ml}$ of plant extract, $1 \mathrm{ml}$ of Molisch's reagent and few drops of concentrated sulfuric acid were added. The presence of purple or reddish indicates the presence of carbohydrates [9].

\section{Test for tannins}

To $1 \mathrm{ml}$ of plant extract, $2 \mathrm{ml}$ of $5 \%$ ferric chloride was added. Formation of dark blue or greenish black indicates the presence of tannins [10].

\section{Test for saponins}

To $2 \mathrm{ml}$ of plant extract, $2 \mathrm{ml}$ of distilled water was added and shaken in a graduated cylinder for 15 minutes lengthwise. Formation of $1 \mathrm{~cm}$ layer of foam indicates the presence of saponins [11].

\section{Test for flavonoids}

To $2 \mathrm{ml}$ of plant extract, $1 \mathrm{ml}$ of $2 \mathrm{~N}$ sodium hydroxide was added. The presence of yellow indicates the presence of flavonoids [12].

\section{Test for alkaloids}

To $2 \mathrm{ml}$ of plant extract, $2 \mathrm{ml}$ of concentrated hydrochloric acid was added. Then, few drops of Mayer's reagent were added. The presence of green or white precipitate indicates the presence of alkaloids [13].

\section{Test for quinones}

To $1 \mathrm{ml}$ of extract, $1 \mathrm{ml}$ of concentrated sulfuric acid was added. Formation of red indicates the presence of quinones [14].

\section{Test for glycosides}

To $2 \mathrm{ml}$ of plant extract, $3 \mathrm{ml}$ of chloroform and $10 \%$ ammonia solution was added. Formation of pink indicates the presence of glycosides [15].

\section{Test for cardiac glycosides}

To $0.5 \mathrm{ml}$ of extract, $2 \mathrm{ml}$ of glacial acetic acid and few drops of $5 \%$ ferric chloride were added. This was underlayered with $1 \mathrm{ml}$ of concentrated sulfuric acid. Formation of brown ring at the interface indicates the presence of cardiac glycosides [12].

\section{Test for terpenoids}

To $0.5 \mathrm{ml}$ of extract, $2 \mathrm{ml}$ of chloroform was added and concentrated sulfuric acid was added carefully. Formation of red-brown at the interface indicates the presence of terpenoids [12].

\section{Test for phenols}

To $1 \mathrm{ml}$ of the extract, a few drops of phenol Ciocalteu reagent were added followed by few drops of $15 \%$ sodium carbonate solution. Formation of blue or green color indicates the presence of phenols [14]

\section{Test for coumarins}

To $1 \mathrm{ml}$ of extract, $1 \mathrm{ml}$ of $10 \% \mathrm{NaOH}$ was added. Formation of yellow indicates the presence of coumarins [14].

\section{Steroids and phytosteroids}

To $1 \mathrm{ml}$ of plant extract, an equal volume of chloroform is added and subjected with few drops of the concentrated sulfuric acid appearance of brown ring indicates the presence of steroids and appearance of bluish-brown ring indicates the presence of phytosteroids [16].

\section{Phlobatannins}

To $1 \mathrm{ml}$ of plant extract, few drops of $2 \%$ HCL were added the appearance of red precipitate indicates the presence of phlobatannins [12].

\section{Anthraquinones}

To $1 \mathrm{ml}$ of plant extract, few drops of $10 \%$ ammonia solution were added, appearance pink precipitate indicates the presence of anthraquinones [12]

\section{MTT assay for cytotoxicity}

The MTT assay (Mossman, 1983) is based on the ability of live but not dead cells to reduce a yellow tetrazolium dye to a purple formazan product. Cells were maintained in Dulbecco's modified Eagle's medium, supplemented with $10 \%$ fetal bovine serum, at $37^{\circ} \mathrm{C}$ in humidified atmosphere with $5 \% \mathrm{CO}_{2}$. 
The cells were plated in 96 well flat bottom tissue culture plates at a density of approximately $1.2 \times 10^{4}$ cells/well and allowed to attach overnight at $37^{\circ} \mathrm{C}$. The medium was then discarded, and cells were incubated with different concentrations of the samples $(25,50,75,100$ and $125 \mu \mathrm{g}$ ) for $24 \mathrm{hrs}$. After the incubation, medium was discarded, and $100 \mu \mathrm{l}$ fresh medium was added with $10 \mu \mathrm{l}$ of MTT ( $5 \mathrm{mg} / \mathrm{ml})$. After $4 \mathrm{hrs}$, the medium was discarded, and $100 \mu \mathrm{l}$ of dimethyl sulfoxide was added to dissolve the formazan crystals. Then, the absorbance was read at $570 \mathrm{~nm}$ in a microtiter plate reader. Cyclophosphamide was used as a positive control (PC) [17].

Cell survival was calculated by the following formula:

Viability $\%=($ Test OD $/$ Control OD $) \times 100$

Cytotoxicity $\%=100-$ Viability $\%$

\section{RESULTS}

Table 1 and Fig. 1 shows the phytochemical analysis.

Table 2 shows the percentage of cell viability of sample and PC against KB cells.

Graph 1 shows the effect of cell viability of sample and PC in KB cells.

Table 1: ???

\begin{tabular}{lll}
\hline S. No & Phytochemical tests & Pineapple extract \\
\hline 1 & Carbohydrates test & + \\
2 & Tannins test & Weakly + \\
3 & Saponins test & - \\
4 & Flavonoids test & Weakly + \\
5 & Alkaloid test & - \\
6 & Quinones test & + \\
7 & Glycosides test & - \\
8 & Cardiac glycosides test & + \\
9 & Terpenoids test & + \\
10 & Phenols test & + \\
11 & Coumarins test & Weakly + \\
12 & Steroids and phytosteroids & Steroids \\
13 & Phlobatannins test & - \\
14 & Anthraquinones test & - \\
\hline
\end{tabular}

+: Present, -: Absent

Table 2: MTT assay

\begin{tabular}{lll}
\hline Concentration $(\mu \mathrm{g})$ & Viability \\
\cline { 2 - 3 } & Sample & PC \\
\hline 25 & 63.64 & 22.31 \\
50 & 52.61 & 22.31 \\
75 & 48.97 & 22.31 \\
100 & 43.17 & 22.31 \\
125 & 35.63 & 22.31 \\
\hline
\end{tabular}

PC: Positive control (cyclophosphamide), C: Control, MTT: 3-(4,

5-dimethyl-2-thiazolyl)-2, 5-diphenyl-2H-tetrazolium bromide

Table 3: ???

\begin{tabular}{lll}
\hline Concentration $(\boldsymbol{\mu g})$ & \multicolumn{2}{l}{ Cytotoxicity } \\
\cline { 2 - 3 } & Sample & PC \\
\hline 25 & 36.36 & 77.69 \\
50 & 47.39 & 77.69 \\
75 & 51.03 & 77.69 \\
100 & 56.83 & 77.69 \\
125 & 64.37 & 77.69 \\
\hline
\end{tabular}

Table 3 shows the percentage of cytotoxicity of sample and PC against KB cells.

Graph 2 shows the effect of cytotoxicity of sample and PC against KB cells.

\section{DISCUSSION}

The main constituents found in the extract were flavanoids, phenols, coumarins, steroids, terpenoids, and quinones. Secondary metabolites such as alkaloids, quinones, and phenols, present in pineapple extract showed anticancer potential. The presence of phenols suggests the antioxidant activity of the extract. Tannins which are a group of phenolic compounds that are known antimutagentic property and can act against cancer cells. Cytotoxicity analysis using varying concentrations of pineapple extract was done. As shown in Tables 1 and 2, the viability of the KB cell lines shows a gradual change as the concentration of the extract is increased. Pineapple extract exhibited increasing cytotoxicity

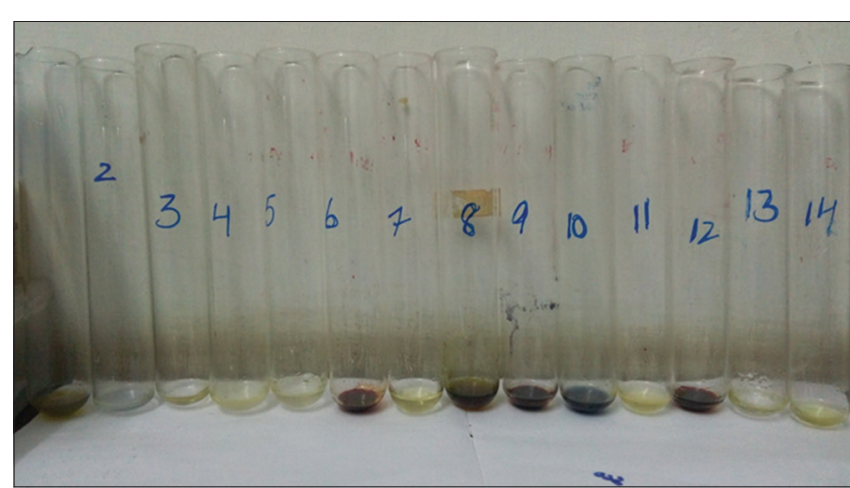

Fig.1: ???

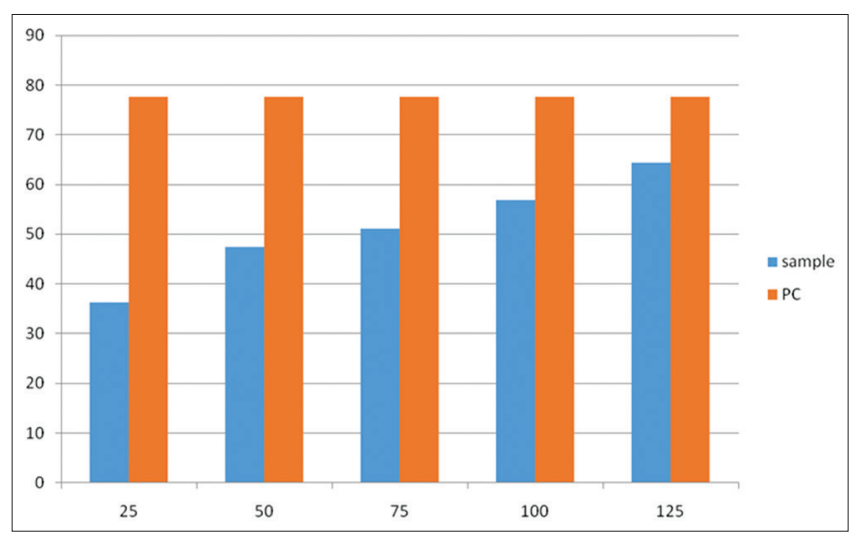

Graph 1: ???

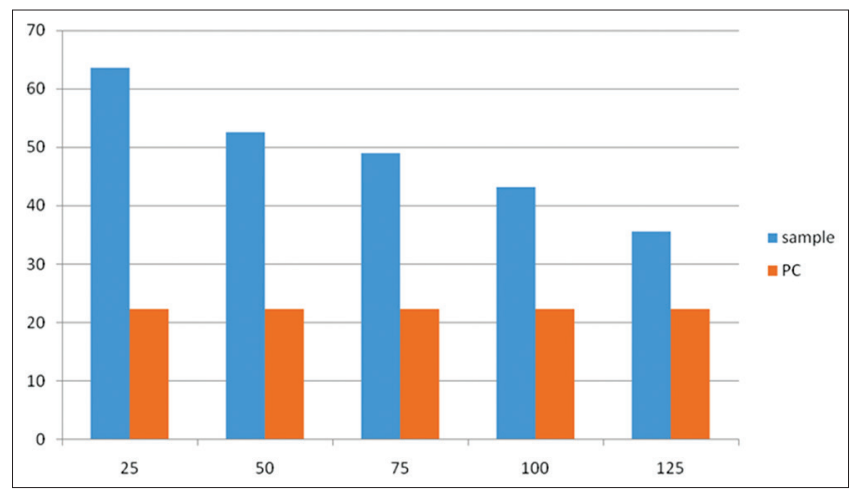

Graph 2: ??? 
with increasing concentration. This is also evident from the graphical representations (Graphs 1 and 2).

\section{CONCLUSION}

Natural products are used widely nowadays to avoid the various side effects caused by carcinogenic drugs. The phytoconstituents found in the extract reveals the antioxidant property of the extract. The study exposed the cytotoxic potential and antitumor properties of pineapple extract. The potential to develop pineapple extract as an anticancer drug is a thrust area for future research in drug designing industry.

\section{REFERENCES}

1. Riss TL, Moravec RA. Use of multiple assay endpoints to investigate the effects of incubation time, dose of toxin, and plating density in cellbased cytotoxicity assays. Assay Drug Dev Technol 2004;2(1):51-62.

2. Decker T, Lohmann-Matthes ML. A quick and simple method for the quantitation of lactate dehydrogenase release in measurements of cellular cytotoxicity and tumor necrosis factor (TNF) activity. J Immunol Methods 1988;115(1):61-9.

3. Niles AL, Moravec RA, Eric Hesselberth P, Scurria MA, Daily WJ, Riss TL. A homogeneous assay to measure live and dead cells in the same sample by detecting different protease markers. Anal Biochem 2007;366(2):197-206.

4. Fan F, Wood KV. Bioluminescent assays for high-throughput screening. Assay Drug Dev Technol 2007;5(1):127-36.

AQ5 5. Phytotoxicity - Pesticides. Province of British Columbia, 2007.

6. Krogmeier MJ, McCarty GW, Bremner JM. Phytotoxicity of foliarapplied urea. Proc Natl Acad Sci U S A 1989;86(21):8189-91.

7. Krstic D, Bjelic D, Nikezic D, Djalovic I. Aluminium in Acid Soils: Chemistry, Toxicity and Impact on Maize Plants. Rijeka, Croatia: INTECH Open Access; 2012.

8. Buczacki S, Harris K. Disorders. Pests, Diseases \& Disorders of Garden Plants. London: Collins; 1998. p. 609.
9. Sofowora A. Screening plants for bioactive agents. Medicinal Plants and Traditional Medicinal in Africa. $2^{\text {nd }}$ ed. Ibadan, Nigeria: Spectrum Books Ltd., Sunshine House; 1993. p. 134-56.

10. Harborne JB. Phytochemical Methods: A Guide to Modern Techniques of Plant Analysis. $3^{\text {rd }}$ ed. New York: Chapman and Hall; 1973. p. 279.

11. Smolenski SJ, Silinis H, Farnsworth NR. Alkaloid screening. V. Lloydia 1974;37(3):506-36.

12. Kapoor LD, Singh A, Kapoor SL, Srivastava SN. Survey of Indian plants for saponins, alkaloids and flavonoids. I. Lloydia 1969;32(3):297-304.

13. Jana S, Shekhawat GS. Phytochemical analysis and antibacterial screening of in vivo and in vitro extracts of Indian medicinal herbs: Anethum graveolens. Res J Med Plants 2010;4(4):206-12.

14. Ayoola GA, Coker HA, Adesegun SA, Adepoju-Bello AA, Obaweya K, Ezennia EC, et al. Phytochemical screening and antioxidant activities of some selected medicinal plants used for malaria therapy in Southwestern Nigeria. Trop J Pharm Res 2008;7(3):1019-24.

15. Sureshkumar CA, Varadharajan R, Muthumani P, Meera R, Devi P, Kameswari B. Pharmacognostic and preliminary phytochemical investigations on the stem of Saccharum spontaneum. J Pharm Sci Res 2009;1(3):129-36.

16. Boxi M, Rajesh Y, Rajakumar V, Praveen B, Mangamma K. Extraction, phytochemical screening and in-vitro evaluation of anti-oxidant properties of commicarpuschinesis (aqueous leaf extract). Int J Pharm Bio Sci 2010;1(4):975-6299.

17. Kolawole OM, Oguntoye SO, Agbede O, Olayemi AB. Studies on the efficacy of Bridelia ferruginea Benth. Bark extract in reducing the coliform load and BOD of domestic waste water. Ethnobotanical Lealf 2006;10:228-38.

18. Mosmann T. Rapid colorimetric assay for cellular growth and survival: Application to proliferation and cytotoxicity assays. J Immunol Methods 1983;65(1-2):55-63.

19. Rajeshwari A. Evaluarion of phytochemical constituents, quantitative analysis and antimicrobial efficacy of potential herbs against selected microbes. Asian J Pharm Clin Res 2015;8(2):232-7.

Author Queries???

AQ3: Kindly provide reference citation

AQ4; Kindly review the sentence.

AQ5: Kindly provide complete reference details

AQ6: Kindly cite reference 19 in text part and also cite all references in chronological order

AQ7: Kindly provide Tables 1 and 3 captions

AQ8: Kindly provide figure 1 captions

AQ9: Kindly provide Graphs 1 and 2 captions 